\title{
The Relationship of the Quality of Corporate Social Responsibility Disclosure to the Financial Performance of Listed Companies in the Indonesia Stock Exchange (SRI-KEHATI Index)
}

\author{
Agus Santoso, Siti Maria Wardayati, Yosefa Sayekti
}

\begin{abstract}
This research was conducted at companies incorporated in the SRI-KEHATI index for the 2015-2018 period. The research samples in the study were 88 companies taken with the criteria of companies that were continuously included in the SRI-KEHATI index during the observation period. The variable used in this study is the quality of disclosure of social responsibility as an independent variable. Whereas the dependent variable uses issuer's financial performance using accounting-based performance proxies using ROA and ROE, market-based performance uses PER. The results showed that the quality of corporate social responsibility disclosure had a significant positive effect on ROE, ROE, and PER.
\end{abstract}

Index Terms - Quality Of Corporate Social Responsibility Disclosure, ROA, ROE, PER

\section{INTRODUCTION}

How big is the role of the Company in the success of sustainable development goals in 2030. In order to increase contributions to sustainable development, corporate social responsibility is part of the company's goal to continue to exist in the eyes of stakeholders. Companies are currently considering CSR to be a major part of their policies and strategies (Alotaibi and Hussainey, 2016). Many companies express CSR as a marketing tool and to improve the quality of corporate earnings (Michaels and Gurning, 2018). The increase in CSR activities in companies is mainly because companies are faced with "green investors" who are increasingly responsive to CSR problems (Santoso et al, 2017). CSR reporting is now one that must be made in the company's annual report to show that the company in running its business is not just maximizing business profits but also actively involved in improving the quality of Human Resources around, helping to protect the surrounding environment and play an active role in improving the company's contribution to sustainable development (Motik et al, 2015). CSR has proven beneficial for enhancing the company's image and business reputation at the local, national and international levels (Garg P, 2016; Nurjanah and

Agus Santoso, Department of Accounting, Faculty of Economics and Business, Jember University, Indonesia

Siti Maria Wardayati, Department of Accounting, Faculty of Economics and Business, Jember University, Indonesia

Yosefa Sayekti, Department of Accounting, Faculty of Economics and Business, Jember University, Indonesia
Mulazid, 2018; Sari and Azizah, 2019; Sutriningsih et al, 2019).

Government regulations requiring social responsibility reporting can improve the quality of reporting rather than the absence of CSR reporting regulations (Habek and Wolniak, 2016; Esteban et al, 2018; Sanchez et al, 2019), in China companies that report CSR increases in quantity are greater after government regulations issued (Chen et al., 2016).

The quality of social responsibility information is reflected in the extent of disclosure and also the completeness of the disclosure made by the company. Disclosure of corporate social responsibility in the annual report becomes a source of information as well as a medium of communication for stakeholders. For investors, the quality and extent of corporate social responsibility disclosure is one of the things that forms the basis of investment decisions.

According to Angelia \& Sinarti (2018) a company's financial performance can be measured by two approaches, namely accounting-based financial performance and also market-based financial performance. Accounting performance describes the company's performance in the past, while market performance illustrates market perceptions of company performance in the future. Although the financial performance of both accounting and market-based companies has different measurement properties, if carried out measurements using data from financial statements that have reliable information, the results should be the same from the two measurement approaches.

This study uses companies incorporated in the SRI-KEHATI index as research objects. The SRI-KEHATI Index is one of the indices on the Indonesia Stock Exchange which is launched and managed in collaboration with the Indonesian Biodiversity Foundation (KEHATI Foundation). With company selection standards that apply the principle of Sustainable Responsible Investment (SRI), as well as environmental, social and governance principles (Environmental, Social and Good Governance (ESG), the SRI-KEHATI Index is now the only reference for investment principles that emphasizes ESG issues in the Indonesian capital market The SRI-KEHATI index also has better 
performance compared to some major indices such as the IHSG, LQ45 and others.

\section{LITERATUR REVIEW AND DEVELOPMENT OF HYPOTHESiS}

\section{A. Stakeholders Theory}

According to Clarkson (1995) stakeholders are people or groups who have rights or interests in a company and its activities in the past, present, and future. These rights or interests are the result of transactions with the company, or actions taken by the company. The stakeholder groups include: Shareholders, Employees, Customers and so on. The stakeholder group is divided into two, namely 1) The main stakeholder group is the group involved in company activities which if cannot be maintained will affect the sustainability of the business. The group consists of shareholders and investors, employees, customers and suppliers. Coupled with public stakeholder groups namely government and society. 2) Secondary stakeholder groups are groups that influence or are influenced by the company but they are not involved in the company's activities and do not directly affect the sustainability of the business. This group consists of the media and various special interest groups (Environment, NGOs, Academics etc.).

According to Friedman \& Miles (2006) stakeholders are classified not only those involved in achieving company goals such as shareholders, employees, suppliers, customers and the general public, but also those who are influenced by the company's actions in achieving its goals. Some of these stakeholders include: trade unions, NGOs, Competitors, Government / DPR / DPRD, creditors, media, the general public, the environment, business partners, academics, future generations.

\section{B. Corporate Social Responsibility}

Lee Preston and James Post (1975) state the term (social responsibility) is a brilliant one, it means something, but it is not always the same for everyone. For some it conveys the idea of legal responsibilities or obligations, for one person, but that can mean social responsibility as ethical behavior, for others. The meaning to be conveyed is "responsible", in causal mode, which is much equated with charitable contributions, or social awareness, many of whom accept it only for "legitimacy" in the context of legitimate "property" / some see it as a kind of high standard application of the behavior of entrepreneurs is higher than citizens in general.

Edwin M. Epstein (1987) provides a definition of CSR in order to link social responsibility, social response, and business ethics. He stated that corporate social responsibility is primarily related to achieving results from organizational decisions on issues or problems which (by some normative standards) are more beneficial than detrimental to the company's stakeholders. Normatively, the truth of the products of corporate activities has become the main focus of corporate social responsibility.

According to Motik et al (2015) in the KADIN handbook on CSR that supports Sustainable Development defines CSR as a guideline for companies to be responsible for the risks of goods and services produced to the surrounding environment and also stakeholders such as customers, employees, investors, distributors, and the community in relation to corporate social responsibility.

There are 4 main focuses in the CSR framework that must be considered by companies, including:

\section{Focus on ethics}

There are 7 (seven) principles of behavior that are considered good and right, namely:

a. Accountability: Accountable for risks to society, the economy and the environment.

b. Transparency: Transparency of policies and programs that pose risks to society and the environment.

c. Ethical behavior: Behavior is based on honesty, fairness and integrity, as a form of concern for humans, animals and the environment. Demonstrate seriousness in reducing policy and program risk.

d. Respecting the interests of stakeholders: respecting, considering and responding to the interests of their stakeholders.

e. Respect the Rules of Law: the law must be respected

f. Respect the norms of international behavior: respect and implement applicable regulations

g. Respect human rights: Respect human rights and recognize the importance of human rights and the universality of human rights.

\section{Focus on content: core subjects and issues}

There are 7 (seven) relevant core subjects consisting of several issues to study the relevance and significance of the company, including:
a. Governance
b. Human rights
c. Employment Practices
d. Living environment
e. Fair Business Practices
f. Consumer Issues
g. Community Engagement and Development

\section{Focus on stakeholders}

The company's stakeholders must have been determined by management in terms of carrying out aspirations and demands for the implementation of CSR carried out by the company.

\section{Focus on the process}

The implementation of CSR activities is focused on reducing the risk of the company's business processes and strategic policies for stakeholders. 


\section{Qualitative Characteristics of Financial Information}

According to the PSAK 2019 Conceptual Framework for Financial Reporting (CFFR), for financial information to be useful, the information must be relevant and represent exactly what is represented. The usefulness of financial information can be improved if the information can be compared, verified, timely, and can be understood.

\section{Fundamental Qualitative Characteristics}

\section{a. Relevance}

Financial information can be said to be relevant if the decisions taken by users can vary. Financial information that can make different decisions if they have predictive value, confirmatory value, or both.

\section{b. Materiality}

Information is said to be material if the omission or misstatement of that information could affect decisions made by users based on financial information about certain reporting entities.

\section{c. Right Representation}

Financial statements represent economic phenomena in words and numbers. In order to be able to show perfect representations perfectly, three characteristics must be possessed namely complete, neutral, and error free.

\section{Qualitative Characteristics of Enhancers \\ a. Comparison}

Comparability is a qualitative characteristic that allows users to identify and understand similarities in, and differences between items. information can be said to be useful if it can be compared with other companies and can also be compared with information at different times. if information about the reporting entity is more useful if it can be compared with similar information about other entities and with similar information about the same entity for other periods and dates.

b. Verification

Verified information can convince users that the information contains an explanation of economic events correctly. Verification can occur directly or indirectly.

c. Timing

Information presented to policy makers in a timely manner will affect the decisions that are taken.

\section{d. Understanding}

Information will be easily understood if the classification, characteristics, and presented clearly and concisely.

\section{Hypothesis Development}

1. The effect of the quality of corporate social responsibility disclosure on accounting-based financial performance.

Based on Stakeholder Theory, corporate image promoted through CSR disclosures can lead to higher profitability in the following year. Thus the company's CSR program improves the company's performance in the future. (Chen et al., 2016).
Return on Assets (ROA) as one of the ratios calculated by investors to find out the level of return or returns to be received for all assets owned, the greater the rate of return will have an impact on the company's stock price in the capital market which will also increase. The better implementation of CSR will have a good impact on the long-term sustainability of the company's financial performance (Sari and Azizah, 2019). One of the company's media to provide information about financial performance is to include ROE in the financial statements. The greater ROE reflects the company's ability to generate high returns for shareholders (Sutriningsih et al (2019).

Previous research found that disclosure of corporate social responsibility has a positive effect on financial performance (Khafa and Laskito (2015); Fauziah et al. (2016); Giannarakis et al (2016); Bidhari and Wardhanie (2017); Manokaran et al (2018); Salvi et al. (2018); Sari and Azizah (2019); Ahyani and Puspitasari (2019), whereas previous studies that found the quality of CSR disclosure had a positive effect on financial performance were revealed by Alotaiby and Hussainey (2016) and Santoso B. et al (2017). Stakeholders and also previous research that found a positive influence between corporate social responsibility and accounting-based financial performance with ROA and ROE measurement tools, researchers put forward a hypothesis:

H1: The quality of corporate social responsibility disclosure has a significant positive effect on Accounting-based financial performance (ROA).

$\mathrm{H} 2$ : The quality of corporate social responsibility disclosure has a significant positive effect on financial performance based on Accounting (ROE).

\section{Effect of quality of corporate social responsibility disclosure on Market-based financial performance.}

The more extensive and clear information provided by company management through annual reports will greatly affect the decisions of external parties in assessing the company's performance both in financial and market terms. The better the assessment of external parties, the better the value of the company in the eyes of investors. So that the signal given by the company can affect the company's stock price. Disclosure of the implementation of CSR on an ongoing basis will be a positive signal from the company and the market will appreciate the share prices of companies that care about CSR activities. The greater the company's concern for CSR, the greater market appreciation of the company's stock price will also affect the earnings of each share (Sari and Azizah, 2019).

Previous research found that disclosure of corporate social responsibility has a positive effect on Sari and Azizah's market-based financial performance (2019) and Ahyani and Puspitasari (2019). Whereas previous research that found the quality of CSR disclosure had a positive effect on financial performance was revealed by Alotaiby and Hussainey (2016) 
The Relationship of the Quality of Corporate Social Responsibility Disclosure to the Financial Performance of Listed Companies in the Indonesia Stock Exchange (SRI-KEHATI Index)

and Santoso B. et al (2017). Based on the signal theory and also previous research that found a positive influence between corporate social responsibility and market-based financial performance, the researcher proposes a hypothesis: H3: The quality of corporate social responsibility disclosure has a significant positive effect on market-based financial performance (PER).

\section{III.RESEARCH METHODS}

The type of research that will be used in this research is explanatory research (explanatory research) which will explain the effect of the quality of social responsibility disclosure on financial performance of companies listed on the Indonesia Stock Exchange (SRI KEHATI index) in 2015-2018. This study will test hypotheses using secondary data derived from published annual company reports that are processed to produce information that can be used as answers to hypotheses that have been prepared. The population in this study are all companies listed on the Indonesia Stock Exchange which are members of the SRI-KEHATI index.

The sampling method in this study uses a purposive sampling method. The criteria used in determining the sample are companies that are continuously included in the SRI-KEHATI index for the 2015-2018 period.

This study uses qualitative measurements in assessing the quality of corporate social responsibility disclosures and examining their effects on the financial performance of companies incorporated in the 2015-2018 SRI-KEHATI index. Data obtained from company annual reports that are sampled will be weighted using the Likerts scale, which gives a value of 1 to 5 in accordance with the index (Beest et al, 2009) that has been used in previous studies by Alotaibi and Hussainey (2016) and Santoso et al (( 2017) attached. The indicators used in assessing the quality of disclosure of social responsibility are relevant, reliability, comprehensible, and comparable aspects.

The financial performance used in this study uses measurements based on accounting performance and market performance. This variable was chosen because it is a variable that is often used by previous researchers so that to test the consistency of research results, the same variables with different objects and years are needed. The formula used is:

\section{a) Return on Assets (ROA)}

Researchers use ROA as a proxy for accounting-based financial performance because this ratio illustrates the efficiency of funds used in the company.

$$
\begin{gathered}
\text { Net profit } \\
\text { Total assets }
\end{gathered}
$$

b) Return on Equity (ROE)

Researchers also use ROE as a proxy for accounting-based financial performance because this ratio is often used by investors to measure the success of a business conducted by a company.

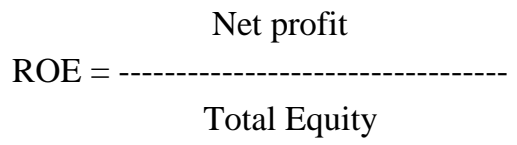

c) Price Earning Ratio (PER)

Potential investors are very interested in Price Earning Ratio because PER is one indicator of a company's performance, the higher this ratio the better the company's performance.

Common Stock Price

Price Earning Ratio =

EPS

Earnings per share is calculated by:

$$
\begin{aligned}
& \text { Net profit } \\
& \text { EPS = } \\
& \text { Number of Shares Outstanding }
\end{aligned}
$$

This analysis is used to find out how much influence the quality of social responsibility disclosure on financial performance (ROA, ROE, and PER). The measurement

\begin{tabular}{|c|c|c|c|c|c|}
\hline $\mathrm{ROA}_{\mathrm{it}}$ & $=$ & $\beta 0$ & + & $\begin{array}{l}\beta 1 . \mathrm{CSRD}_{\text {it }} \\
\text { (1a) }\end{array}$ & + \\
\hline $\mathrm{ROE}_{\mathrm{it}}$ & $=$ & $\beta 0$ & + & $\begin{array}{l}\beta 1 . \mathrm{CSRD}_{\text {it }} \\
(1 \mathrm{~b})\end{array}$ & + \\
\hline $\mathrm{PER}_{\mathrm{it}}$ & $=$ & $\beta 0$ & + & $\begin{array}{l}\beta 1 . \mathrm{CSRD}_{\text {it }} \\
(1 \mathrm{c})\end{array}$ & + \\
\hline
\end{tabular}
model uses simple linear regression that regresses the quality of social responsibility disclosure to performance.

The statistical equation is arranged as follows:

Model 1 (simple linear regression without control variables):

\section{A. Description of Research Object}

The population of this research is companies listed on the IDX which are included in the SRI-KEHATI index. In taking the sample, the researcher used the criteria of the company which was continuously included in the SRI-KEHATI index for the 2015-2018 period. The number of companies included in the SRI-KEHATI index per period numbered 25 companies and those that continuously entered and met the criteria for the sample amounted to 22 companies where for 4 years the samples obtained were 88 objects of observation. This study uses secondary data obtained by researchers from the company's annual report downloaded from www.idx.co.id and also the company's official website as a comparison data.

\section{B. Descriptive Statistics}

Descriptive statistics are used to determine data characteristics by describing data from variables used as research in the form of quality of corporate social 
responsibility disclosure, accounting-based financial performance (ROA, and ROE), and market-based financial performance (PER) including average value, value maximum, minimum value, and standard deviation.

Table 1. Research Descriptive Statistics

\begin{tabular}{cccccc}
\hline Variabel Penelitian & N & Min & Max & Mean & $\begin{array}{c}\text { Standar } \\
\text { Deviasi }\end{array}$ \\
\hline CSR & 88 & 28 & 35 & 31 & 1,8937 \\
ROA & 88 & 1,09 & 46,66 & 7,04 & 8,2024 \\
ROE & 88 & 1,89 & 135,86 & 18,55 & 24,84 \\
PER & 88 & 5,75 & 64,25 & 18,61 & 10,50 \\
\hline
\end{tabular}

\section{Normality Test}

Data normality is one of the assumptions that must be met in the distribution of research data. The purpose of the normality test in this study is to test whether in the model, the interruption variable has a normal distribution. One of the tools used to test data normality is the Kolmogorov-Smirnov (K-S) non-parametric statistical test by setting a confidence level (a) of 5\%: $\mathrm{H} 0$ residual data are normally distributed, Ha: residual data are not normally distributed.

Table 2. Normality Test

\begin{tabular}{ccc}
\hline Variabel & $\begin{array}{c}\text { Nilai Kolmogorov } \\
\text { Smirnov }\end{array}$ & explanation \\
\hline Unstandarized ROA & 0,112 & Normal distribution \\
Unstandarized ROE & 0,196 & Normal distribution \\
Unstandarized PER & 0,200 & Normal distribution \\
\hline
\end{tabular}

\section{Regression Analysis}

\begin{tabular}{ccccc}
\hline $\begin{array}{c}\text { Dependent } \\
\text { Variable }\end{array}$ & $\begin{array}{c}\text { Independent } \\
\text { Variable }\end{array}$ & $\begin{array}{c}\text { Koefisien } \\
\text { Regresi }\end{array}$ & Sig. & Explanation \\
\hline ROA & constant & 0,156 & - & - \\
& CSR & 0,279 & 0,001 & Significant \\
\hline ROE & constant & 0,152 & - & - \\
& CSR & 0,267 & 0,000 & Significant \\
\hline PER & constant & 0,040 & - & - \\
& CSR & 0,340 & 0,000 & Significant \\
& & & &
\end{tabular}

the results of testing the effect of the quality of corporate social responsibility disclosure on accounting-based financial performance (ROA) obtained a significance value of 0.001 which has a value smaller than 0.05 . This shows that the variable quality of corporate social responsibility disclosure has a significant positive effect on accounting-based financial performance (ROA). So it can be concluded that hypothesis 1 is accepted.

The results of this study are in line with research conducted by Khafa and Laskito (2015); Fauziah et al. (2016); Giannarakis et al (2016); Alotaiby and Hussainey (2016); Santoso B. et al (2017); Bidhari and Wardhanie (2017);
Manokaran et al (2018); Salvi et al (2018); Sari and Azizah (2019); Ahyani and Puspitasari (2019) found that disclosure of corporate social responsibility has a positive effect on accounting-based financial performance (ROA).

The company's image is a positive thing given by the company to stakeholders and shareholders. Positive responses given by stakeholders and shareholders to the company in the form of trust and acceptance of products produced by the company so that the company will get significant profits on an ongoing basis by conducting Corporate Social Responsibility (CSR). An increase in profits will automatically increase the value of the company's assets.

Return on Assets (ROA) as one of the ratios calculated by investors to find out the level of return or returns to be received for all assets owned, the greater the rate of return will have an impact on the company's stock price in the capital market which will also increase. The quality of corporate social responsibility disclosure can be seen from how the company reports in the annual report. Implementation of development, improvement and environmental quality improvement programs. Programs to improve the quality of human resources within the company, the application of K3 (Employment, Health, and Work Safety), community empowerment around the company either through educational scholarship programs, public health and improving community welfare. This is based on reporting principles that are based on relevant, reliable, easy to understand, understandable, and comparable. So companies can run their programs in a measurable manner and maintain company sustainability.

the results of testing the effect of the quality of corporate social responsibility disclosure on accounting-based financial performance (ROE) obtained a significance value of 0,000 which has a value smaller than 0.05 . This shows that the variable quality of corporate social responsibility disclosure has a significant positive effect on accounting-based financial performance (ROE). So it can be concluded that hypothesis 2 is accepted.

The results of this study are in line with research conducted by Bidhari and Wardhanie (2017); Salvi et al (2018); Sari and Azizah (2019); Ahyani and Puspitasari (2019) found the quality of CSR disclosure had a positive effect on accounting-based financial performance, which was proxied by ROE.

One of the keys to integrated marketing is that various marketing activities are used to communicate and convey value to customers (Kartini, 2013: 23). Disclosure of CSR activities carried out by the company is a positive value, if the company conveys a positive value it is expected that stakeholders and shareholders will give a positive response also in the form of trust. The trust that the company gets in the form of receipt of products produced by the company which if this continues will affect the company's financial performance for the better. So it can be concluded that at the 
moment the implementation of CSR can be used as one of the company's marketing strategies

the results of testing the effect of the quality of corporate social responsibility disclosure on market-based financial performance (PER) obtained a significance value of 0.001 which has a value smaller than 0.05 . This shows that the variable quality of corporate social responsibility disclosure has a significant positive effect on market-based financial performance (PER). So it can be concluded that hypothesis 3 is accepted.

The results of this study are in line with research conducted by Sari and Azizah (2019), Ahyani and Puspitasari (2019), Alotaiby and Hussainey (2016) and Santoso B. et al (2017) find that disclosure of corporate social responsibility has a positive effect on financial performance based on market.

The more extensive and clear information provided by company management through annual reports will greatly affect the decisions of external parties in assessing the company's performance both in financial and market terms. The better the assessment of external parties, the better the value of the company in the eyes of investors. So that the signal given by the company can affect the company's stock price. Disclosure of the implementation of CSR on an ongoing basis will be a positive signal from the company and the market will appreciate the share prices of companies that care about CSR activities. The greater the company's concern for CSR, the greater market appreciation of the company's stock price will also affect the earnings of each share (Sari and Azizah, 2019)

The contribution of this research is that companies that implement social responsibility programs by applying relevant principles, are reliable, easy to understand, and can be compared in activity reports that are part of the company's annual report are expected to provide benefits, namely improving the relationship between company management and stakeholders interests so that the company's goals in increasing profits are also accompanied by increased social responsibility as an inseparable part of the company's strategic plan.

The second contribution, companies should not have to worry about financial performance because if the planning is done well then the corporate social responsibility program will actually increase financial performance. Where employee performance will increase, production costs are more efficient, products are increasingly preferred by customers because they are "green products". So that with good financial performance, social responsibility programs can be further improved to various segments that have been carried out both to improve human resource capabilities, the application of SOPs on Labor, Occupational Safety and Health, planting tree seedlings as an educational step to the community to get together protecting the environment, educational scholarships, improving health, and involving community groups.
Third Contribution, companies that have implemented GRI-4 in social responsibility reports that are part of the annual report based on relevant, reliable, easy to understand, and comparable principles are expected to further improve quality programs, accommodate the needs of all stakeholders, not violate regulations that have been issued by the government. So the higher the quality of corporate social responsibility disclosure, the greater the company's contribution in the success of the sustainability development program launched by the government.

\section{CONCLUSION}

This study examines the quality of corporate social responsibility disclosure on the financial performance of listed companies listed on the Indonesia Stock Exchange in 2015-2018 (SRI-KEHATI index), the independent variable in this study is the quality of corporate social responsibility disclosure while the dependent variable is the company's financial performance proxy with accounting-based financial performance (ROA and ROE) and market-based financial performance (PER), the sample used in this study amounted to 88 companies. Some conclusions are the answers to the main problems raised by this study, as follows:

1. Quality Disclosure of corporate social responsibility has a significant positive effect on accounting-based financial performance (ROA). This means that the higher the quality of corporate social responsibility disclosure will further enhance accounting-based financial performance (ROA)

2. Quality Disclosure of corporate social responsibility has a significant positive effect on accounting-based financial performance (ROE). This means that the higher the quality of corporate social responsibility disclosure will further enhance accounting-based financial performance (ROE)

3. Quality Disclosure of corporate social responsibility has a significant positive effect on market-based financial performance (PER). This means that the higher the quality of corporate social responsibility disclosure will further enhance market-based financial performance (PER).

\section{REFERENCES}

[1] Ahyani, R. dan W. Puspitasari. 2019. The Influence of Corporate Social Responsibility Against Financial Performance in Property and Real Estate Companies Listed on the Indonesia Stock Exchange in 2013-2017. Jurnal Akuntansi Trisakti. Volume. 6 Nomor. 2 : 245-262.

[2] Alotaibi, K. dan K. Hussainey. 2016. Quantity versus quality: the value relevance of CSR disclosure of Saudi companies. Corporate Ownership and Control Journal. Vol 13. Issue 2

[3] Angelia, N. P., dan Sinarti. 2018. Relationship Analysis of Financial Performance Based on accounting and financial performance based on market on companies registered in the Jakarta Islamic Index (JII) with CSR disclosure as a moderation variable. Journal of Applied Managerial Accounting. Vol. 2. No. 1. Page 88-96.

[4] Anggraeni, D. Y. dan C. D. Djakman. 2017. Slack Resources, Board Feminism, and Quality of Corporate Social Responsibility Disclosure. Jurnal Akuntansi dan Keuangan Indonesia. Volume 14 Nomor 1. 
[5] Bidhary, S. C. dan A. P. Wardhanie. 2017. Corporate Sosial Responsibility And Financial Performance: Evidence From Indonesian Banking Sector. International Conference and Call for Papers. Jember.1599-1613

[6] Cheng, S., K. Z. Lin, dan W. Wong. 2016. Corporate sosial responsibility reporting and firm performance: evidence from China. J Manag Gov. 20:503-523. Springer.

[7] Clarkson, M. B. E., 1995. A Stakeholder Framework for Analyzing and Evaluating Corporate Social Performance. Academy of Management Review. Vol. 20 No. 1, 92-117.

[8] Epstin, E. M. 1987. The Corporate social policy process: beyond business ethics, Corporate Social Responsibility, and Corporate social responciveness. California Management Review. 29. 99-114

[9] Fauziah, G., A. K. Irwanto, dan M. Syamsun. 2016. The Influence of CSR Disclosures on Company Value on the LQ45 Index. Manajemen IKM. Vol. 11 No. 1

[10] Friedman, A. L., S. Miles. 2006. Stakeholders Theory and Practice. New York. Oxford University Press.

[11] Garg P. 2016. CSR and corporate performance: evidence from India. Indian Institute of Management Calcutta. 43(4):333-349.

[12] Giannarakis, G., G. Konteos, E. Zafeiriou, dan X. Partalidou. 2016. The Impact Of Corporate Sosial Responsibility On financial Performane. Investment Management and Financial Innovations. Volume 13. Issue 3.

[13] Habek, P. dan R. Wolniak. 2016. Assessing the quality of corporate sosial responsibility reports: the case of reporting practices in selected European Union member states. Qual Quant. 50:399-420. Springer.

[14] IAI. 2018. Financial Accounting Standards per effective January 1, 2019. Jakarta. Dewan Standar Akuntasi Keuangan Ikatan Akuntan Indonesia.

[15] Khafa, L. dan H. Laskito. 2015. The Influence of CSR, Company Size, Leverage, and Investment Decisions on Financial Performance and Firm Value. Diponegoro Journal of Accounting. Volume 4. Nomor 4.

[16] Manokaran, K. R., S. Ramakrishnan, S. S. Hishan, dan K. Soehod. 2018. The impact of corporate sosial responsibility on financial performance: Evidence from Insurance firms. Management Science Letters 8. 913-932.

[17] Motik, S. S., S. Moersjid, M. D. Nurani, dan M. R. N. Rodyati. 2015. KADIN Guidelines on Corporate Social Responsibility (CSR) to Support Sustainable Development. MM-CSR Universitas Trisakti.

[18] Nurjanah dan Mulazid. 2018. Effect of Service Quality and Corporate Social Responsibility on Company Image. Jurnal Muqtasid. 9(1):40-53

[19] Preston, L.E., \& J. E. Post. 1975. Private Management and public policy: The principle of public responsibility. Englewood Cliffs, NJ. Prentice Hall.

[20] Salvi, A., F. Petruzzella, dan A. Giakoumelou. 2018. CSR and Financial Performance: Trick Or Treat? A Longitudinal Study on Holistic CSR Practices. International Journal of Business and Management. Vol. 13. No. 6.

[21] Sanchez, I. M. G., N. Hussain, J. M. Ferrero, dan E. R. Barbadillo. 2019. Impact of disclosure and assurance quality of corporate sustainability reports on access to finance. WILEY Corporate Sosial Responsibility and Environmental Management. 26:832-848.

[22] Santoso, B., Y. Sayekti, dan A. B. Sulistyo. 2017. The Influence of the Quality of CSR Disclosures on the Financial Performance of Mining Companies Listed on the Indonesia Stock Exchange. International Journal of Sosial Science and Business. Vol. 1 (2) pp. 127-133.

[23] Sari, K.C. dan Azizah, D.F. 2019. The Influence of Corporate Social Responsibility (CSR) on Corporate Financial Performance (Study in the Agricultural Sector Listed on the Indonesia Stock Exchange for the Period of 2016-2018). Jurnal Administrasi Bisnis (JAB). Vol. 73 No. 1

[24] Sutriningsih, Handajani, L., Rifa'I, A. 2019. Financial Performance Mediates the Effect of Corporate Social Responsibility and Capital Structure on Company Value. E-Jurnal Akuntansi Universitas Udayana Vol.27.1. 764-791

[25] Global Sustainability Standard Board. 2016. GRI Standar. www.globalreporting.org. (diakses 2 Maret 2020)
[26] Bursa Efek Indonesia. 2018. Issuer's Annual Report http://www.idx.co.id/perusahaan-tercatat/laporan-keuangan-dan-tahun an/ (diakses 16 Maret 2020). 